\title{
Financial Management Practices, Firm Growth and Profitability of Small and Medium Scale Enterprises (SMEs)
}

\author{
Alhassan Musah ${ }^{1}$, Erasmus Dodzi Gakpetor ${ }^{1}$, Portia Pomaa ${ }^{2}$ \\ ${ }^{1}$ School of Business, Dominion University College, Ghana \\ ${ }^{2}$ University of Ghana Business School, University of Ghana, Ghana \\ a.musah@duc.edu.gh
}

\begin{abstract}
The study examined financial management practices using four components: working capital management practices, capital structure management, accounting information and financial reporting practice, and the use of capital budgeting techniques and fixed assets management. Performance of SMEs was examined from the context of profitability measured by Return on Assets and of growth. The study sampled 100 SMEs from Accra with data collected through the administration of a questionnaire. Data were analysed using descriptive statistics and Pearson correlation analysis. The results of the descriptive statistics revealed that working capital management practices had the highest mean score, followed by accounting information and financial reporting practices, capital structure management and finally, the use of capital budgeting techniques and fixed assets management, in that order. The Pearson correlation analysis showed a positive association between the four components of financial management practices and between SMEs profitability and growth. The results emphasize the need for SMEs to improve on their financial management practice to improve the profitability and growth of these firms. It is recommended that the use of capital budgeting techniques be improved, as this area of financial management, even though it impacts positively on the performance of SMEs had the least score. Most importantly, the managers of SMEs should use discounted cash flow techniques to evaluate investment and projects before committing the resources of the company. SMEs are encouraged to adopt IFRS for SMEs to enhance their financial reporting practices. This will also improve their decision making and access to capital which will allow these SMEs to expand.
\end{abstract}

Keywords: Financial management practices, SMEs, Growth, Profitability

\section{Introduction}

There is growing recognition of the important role small and medium enterprises (SMEs) play in economic development in both developed and developing countries (Muneer 2017; Selvanayaki 2016; Karadag, 2015; Jindrichovska, 2013; Abor \& Quartey, 2010). SMEs have been described variously in previous literature to be the seed for larger businesses, good and reliable job creator and an important contributor to economic growth and development (Muneer, 2017; Abor \& Quartey, 2010). Research has shown that the SMEs sector in most developing countries employs the majority of the urban dwellers and labour force and by extension provides incomes to the government through taxes and their household (Kilonzo \& Ouma, 2015). SMEs complement the activities of the larger scale industries through their integration into the mainstream of industrial development by providing the industries with critical parts and components as well as by expanding into the international markets (Ahiawodzi \& Adade, 2012; Madurapperuma, Thilakerathne and Manawadu, 2016). Poor financial management has been posted as the main cause of SMEs failure (Arinaitwe, 2006; Muchira 2012). Mazzarol (2015) argues that there is a positive association between the performance of a business and the level of training and knowledge in bookkeeping and financial management practices.

Pandey (2004) defines financial management as a discipline that deals with the financial decisions that a firm make using some financial tools of analysis. Gitman (2011) on the other hand defines financial management as the concept of time, money and risk and how they are related to each other. According to Mazzarol (2015), financial management practices in SMEs are different from those found in larger firms, due to the nature of their cash flow cycle, their working capital management challenges, and SMEs' difficulty in raising external finance through debt or equity. Other studies argue that most SMEs have inadequate financial management and accounting systems; different from those used by large firms, and that SMEs also have the inadequate skilled personnel to manage those funds (Muneer 2017; Kilomzo \& Ouma, 2015; Turyahebwa, 2013). Research has shown that 60 percent of SMEs fail within a few months of their operation (Karadag, 2015; 
Benedict \& Matsotso, 2014; Ahmad \& Muhammed Arif, 2015). One major reason for the collapse of SMEs is poor or lack of proper bookkeeping and accounting practices which are components of financial management practices (Bowen, 2009; Germain 2010; Kitinga, 2013).

While it has been established that the use of appropriate bookkeeping, financial reporting and management accounting, Practices are important to the survival of SMEs (Bowen, 2009; Isa, Saleh \& Sapiei, 2007), scarcely will you find sufficient reported research on the subject in the sector, particularly in Ghana where just a handful of studies has been reported in recent times. Studies on SMEs in Ghana have focussed on some aspects of financial management practices like bookkeeping, and to a lesser extent working capital management without comprehensively examining the entire financial management practices of SMEs and how these can affect their growth and profitability. For instance, some studies have examined accounting and bookkeeping practices of SMEs in different contexts in Ghana and other parts of Africa (Musah, 2017; Agbemava 2016; Dawuda \& Azeko, 2015; Owusu 2015; Mutua 2015; Boame 2014; Amoako 2013; Maseko \& Manyani, 2011). Other studies have also examined access to finance and credit for SMEs in Ghana (Forkuoh \& Li, 2015; Asamoah, 2014; Amoako, 2013; Ahiawodzi \& Adade, 2012; Abor \& Quartey, 2010). Poor financial management has been declared as the main cause of SME failure (Muchira, 2012; Arinaitwe, 2006). Previous studies in other jurisdictions have established that most SMEs are owner-managed, where the owner performs most of the financial management tasks alone or with some unskilled staff, and this scenario affects the performance and growth of these firms (Mazzarol et al. 2015; Uwonda, 2013; Amoako, 2013; Abanis 2013; OECD, 2010).

Even though SMEs globally have similar characteristics, the environments within which they operate affect their financial management practice. The need to understand the impact financial management practices can have on the growth and profitability of SMEs is critical so as to provide policy recommendation in the midst of little or no literature on the subject matter in the Ghanaian context. This study is aimed at addressing these discrepancies in the literature by examining the financial management practices of SMEs in Ghana and how these affect the performance of these firms. The study makes significant contributions to: Research, Policy, and Practice. At the moment there is little or no literature that has examined financial management practices of SMEs in Ghana and their possible impact on growth and profitability. The findings of this study contribute to the literature on SMEs and on measures to ensure their viability. The findings of this study provide a comprehensive picture of the financial management practices of SMEs. This will in turn lead to a better understanding of this phenomenon and thereby the development of more effective strategies to aid the effective operation of the SMEs. The findings and recommendations of this study are useful in the advocacy efforts of policymakers as well as for designing interventions and for implementing programmes to improve the financial and management accounting practices among SMEs. The information on SMEs' accounting practices and financial performance provide invaluable insights and inputs, especially to the government, in assessing whether further assistance ought to be provided to SMEs.

\section{Literature Review}

The Concept of Financial Management Practices: The term finance management practices is used to represent the management of funds and how the funds are used to achieve the objectives of the organization and shareholders' value maximization (Chandra, 2011; Kilonzo \& Ouma, 2015). According to Kitonga (2013) typical financial management practices in organizations include an accounting information system, fixed assets management, working capital management, financial reporting and analysis, capital structure management etc. These components of financial management practices are supported by Kilonzo and Ouma (2015). Muneer, (2017) also sees accounting information systems as well as working capital management as critical components of financial management. Zietlow et al., (2007) see financial management as the creation of wealth, planning and monitoring of a business' financial assets, improving its profitability and generating the required return to capital providers. In short, financial management practices include all aspects of management that affect the finances of the company and what is needed to achieve the overall objective of the organization. This includes working capital management, long-term financial management and capital structure management, accounting information and financial reporting practices, capital budgeting etc. Kitonga (2013) defines that an accounting information system is the recording of transactions using 
computers with the aid of accounting systems and techniques which are used to record and analyse business transactions for the purpose of preparing a financial statement for users. A proper accounting information system is at the heart of proper bookkeeping and financial analysis for decision making (Muneer et al. 2017). Research on SMEs globally all emphasise the importance of accounting information system for their survival and growth (Lavia-Lopez \& Hiebl, 2014; Chen et al. 2013; Amoako, 2013). Gitman (2011) argues that information from financial statements is useful for planning, evaluation and decision making.

The management of a firm capital structure involves the choice of the right mix of debt and equity capital that will maximize the profitability of the firm (Romney, 2009). In Ghana access to finance is a major challenge to most businesses especially for SMEs and they struggle to meet the requirement of the financial institutions (Abor \& Quartey, 2010). Also access to finance has been a major challenge to SMEs in developing countries especially Ghana and as such can have implications for financial management practices and profitability (Muneer2017; Amoako, 2013; Abor \& Quartey, 2010). This notwithstanding, the management of working capital is very critical and one of the major financial management decisions as it has serious implications on the financial performance of every company (Musah, 2017). This means that it is important for SMEs to take a serious look at how they manage their capital structure to reduce the burden on their cash flows. It is argued that firms in their early stages do not require so much debt capital as this will enormous burden on their cash flow which could result in liquidation challenges (Muneer, 2017) According to Kitonga (2013), fixed assets management is an important component of financial management practices as it represents the long-term investment decision of SMEs. Investment in these assets requires huge capital outlay and as such it is important that they are managed well when acquired. Karadag (2015) argue that it is not enough to be concerned only about the purchase price of fixed assets, but also the total cost of ownership. If the right decision was taken in the acquisition of the assets, it would impact positively on profitability (Mazzarol et al. 2015).

The Concept of SMEs: There are several definitions of SMEs depending on the context. Most of these definitions either use the number of employees or turnover to define what constitutes SMEs. Muneer et al. (2017) defined an SME, according to the State Bank of Pakistan, to be an organization that is not listed on the Stock Exchange and does not have employees of more than 500 for a manufacturing business and 50 employees for a trading or service organization. Study on SMEs in Kenya defined an SME as a business whose number of employees ranges from 10 to 250. The National Board for Small Scale Industries (NBSSI) in Ghana defines SMEs using both number of employees and assets. NBSSI defines SMEs as having employees ranging from 10 to 150 and to have fixed assets of 10 million Ghana cadies. SMEs play a significant role in the Ghanaian economy by way of employment and its contribution to Gross Domestic Product (GDP) (Abor \& Quartey, 2010; Amoako 2013). Good financial management practices contribute significantly to the growth, survival and profitability of SMEs (Turyahebwa et al. 2013).

Empirical Literature: Accounting information system and financial reporting practice and analysis and SME performance accounting information system include all the system that enable financing reporting and analysis for decision making. Several studies have found a positive and significant association between financial reporting practices and SMEs' performance. Agbemaya, (2016) examined the impact of financial management practices on the performance of SMEs in the Ho Municipality. The study sampled 200 SMEs from the municipality and used descriptive analysis as well as correlation analysis to achieve the objective of the study. The outcomes of the study showed that there was a positive association between proper financial reporting practices and profitability of SMEs. The study concluded that sound financial reporting practices assist in decision making as well as help SMEs to access capital and expand their operations.in a related study Musah (2017) study on SMEs bookkeeping practices and its effect on growth and performance reported a positive association between SMEs accounting practices and performance. Mutua (2015) examined the effect of financial accounting practices on the growth of SMEs in Chuka Town, Kenya. The study results show that the majority of SMEs do not keep proper books of account, which affect their ability to make proper business decisions, fulfil their tax obligations, and raise the needed capital from creditors or banks to support their operations. Finally, the study concluded that proper bookkeeping practices influence the growth and financial performance of SMEs in Kenya. 
Working Capital and Cash Flow Management and Performance of SMEs: According to Mazzarol et al. (2015) in their study they argued that cash flow management and working capital management are the most important aspect of financial management practices. It was argued, that an organization cannot operate without a reliable cash flow or liquid assets, which are the major component of working capital management. Cash flows are generated from sales and eventually receivables which suggest that cash flow problems can be traced to declining sales or increase in irrecoverable debt which will affect the performance of the organization (Muneer et al., 2017). In cases like this, the owner/manager must inject new cash into the business or borrow to finance liabilities due, or at best reduce cost in order to survive (Mazzarol et al. 2015). To this end, the cash cycle of an SME, which is the summary of its working capital, is very critical for the success of the business. The main thrust of these studies is that the more efficiently an SME, or any firm for that matter, manages it working capital properly, the better its chances of boosting the profitability of the organization.

Capital Structure Management and Profitability of SMEs: The Capital structure is related to the source of finance for the business and has some implications on the performance of the firm (Mazzarol et al. 2015). Capital structure represents the right mix of debt and equity to finance the operations of a business. The success of SMEs in Ghana's dynamic business environment depends largely on their capacity to being able to determine the right mix of capital structure that will ensure that shareholders value are maximized and other stakeholder interest also taken care of studies have shown that the capital structure management of SMEs especially in developing countries depends largely on their ability and capacity to manage risk associated with their business cash flows prudently (Karadag, 2015; Kennedy, 2006). The SMEs sector in Ghana continues to dominate business activities despite the numerous challenges they go through and the environmental challenges confronting them. The Type of finance SMEs choose affect their capital structure which have implication for their bottom line (Musah, 2017). In a study, Abor (2007) among other things examined how SMEs capital structure affects their financial performance. The study adopted a quantitative approach using secondary data and found that long-term debt was positively associated with gross profit margin of SMEs. The study also reported a negative association between short-term finance and a gross profit margin of SMEs in Ghana and South Africa. Other studies on financial management practices that included capital structure management reported a positive association between the two variables suggesting that SMEs will improve their financial performance by choosing the right mix of debt and equity to reduce risk and at the same time enjoy some tax shields from the interest obligations.

Capital Budgeting and Non-Current Assets Management and Profitability of SMEs: Capital investment decisions are critical business decisions because of the financial consequence of those decisions (Kilonzo \& Ouma, 2015). Brigham's (1995) capital budgeting decisions are more critical for SMEs than for larger organizations since a wrong decision can affect the survival of the business. Because of the importance of capital investment decisions to business, finance literature has proposed various techniques that should be used to evaluate the financial viability of this investment before committing the organization's resources to it (Muneer et al. 2017). Various techniques that can be used to evaluate investment in capital assets include: a payback period with its attendant variations in discounted payback methods, accounting rate of return or return on investment, net present value, internal rate of return etc. the overall objective of an organization's financial management strategy is to maximize the value of shareholder wealth. The money for this kind of investment in developed countries with proper financial markets relies on long-term debt, but same cannot be said for Ghana, as most SMEs do not have access to such long-term capital in Ghana. The Ghana Stock Exchange (GSE) in its attempt to address the problems faced by SMEs in listing or raising funds through this exchange embarked on a project to create an alternative exchange which might help eliminate the challenges faced by SMEs in raising funds through the exchange, called the Ghana Alternative Exchange (GAX).

Tauringana and Afrifa (2013) argue that many SMEs who have some elements of working capital management practices are able to enhance the cash conversion cycle thereby improving their profitability. All the studies reviewed agree that effective working capital management practices are positively associated with the profitability of SMEs though this project has been in play for a long time, the GSE is still faced with difficulty in getting SMEs to raise fund through GAX. Some few SMEs have taken advantage of the new opportunity to list and raise equity capital but the challenge for SMEs to be able to list even on the Alternative 
Stock Exchange still persists. The majority of studies of financial management practices of SMEs report that most of SMEs use the payback method or the discounted payback method in evaluating projects compared to a larger organization where the net present value method is preferred (Jindrichovska, 2013; Kilonzo \& Ouma, 2015; Turyahebwa, 2013). What is common among most of the studies on financial management practices, that have included investment and capital budgeting as a major component of financial management practice, is the fact that they report a positive association between effective capital investment and budgeting and SMEs performance.

Conceptual Framework: The grand mean of 3.0 shows that SMEs pay the least attention to capital budgeting and fixed assets management compared to the other component of financial management practices in Ghana. The framework represent above shows that effective working capital management practices, capital structure management, accounting information system and financial reporting and analysis and capital budgeting and management of fixed assets are the major components of financial management practices and influence the profitability of SMEs in Ghana. Even though all the components of financial management practices in the framework above influence profitability, it is expected that working capital management will have the most significant effect on the profitability of SMEs in line with the previous literature.

Figure 1: Conceptual Framework of Financial Management Practices and SME Performance

\begin{tabular}{|l|l|}
\hline $\begin{array}{l}\text { Working capital management } \\
\text { practices }\end{array}$ \\
$\begin{array}{l}\text { Accounting information } \\
\text { system and financial } \\
\text { reporting practice and } \\
\text { analysis }\end{array}$ \\
\hline $\begin{array}{l}\text { Capital structure } \\
\text { management / financing }\end{array}$ \\
\hline $\begin{array}{l}\text { Capital budgeting and non- } \\
\text { current assets management }\end{array}$ \\
\hline
\end{tabular}

\section{Research Methodology}

In terms of research strategy, the study adopts the survey approach as it seeks to survey SMEs owners and managers of their views on the impact of financial management practices on the performance of their organizations. The study also adopted the purposive sampling technique to sample respondents for the study. The purposive sampling technique is a non-probabilistic sampling method that allows the researcher to choose respondents that best fit the study in a non-probabilistic manner. Under this approach, the only sample with the characteristics that fits the objectives of the study is selected. The target population for the study is SMEs that have formal structures and good organizational structure where financial management practices are practiced. In this regard 250 questionnaires were issued and 180 were retrieved. However, a good number of the SMEs that responded to the questions answered no applicable to most of the financial management practice rendering them invalid for the study. These questionnaires were therefore dropped leaving a sample of 100 SMEs that fit the characteristics needed for the study. The study focused on only SMEs that have a formal structure and as such excluded market men and women who do not have a proper business structure in place to enable them to to practice any form of financial management. The data collected was first coded into SPSS and excel to enable the appropriate statistical tools to be applied in the data analysis. 


\section{Analysis and Discussion}

Respondent Demographics: A total of 150 questionnaires were sent out to SMEs, but only 100 were filled and returned representing an 83\% response rate. Each respondent was picked from one SME, meaning that 100 SMEs were sampled for the study. A response rate of $83 \%$ is considered acceptable as per examples from previous studies and can be used for making a statistical inference (Selvanayaki, 2016). The analysis is therefore based on the responses gathered from the management of these companies, mainly the Chief Executive Officer (CEOs), Finance Directors and Accountants. The study is unique in the sense that most of the studies examined a component of financial management such as capital structure, bookkeeping and accounting records and firm performance and not examining all the major components in one study. The results show that $50 \%$ of the respondents were financed directors while $40 \%$ were chief executive officers and $10 \%$ accountants. These respondents are very crucial in their respective organization regarding the capital source. This means that the respondents had knowledge in the subject matter under study as they were in charge of those decisions.

Financial Management Practices of SMEs: The study measured management practices using four key indicators, working capital management practices, accounting information system and financial reporting and analysis, capital structure and financing and capital budget and management of non-current assets. Each component of financial management practices was measured as were a number of variables where respondent was required to rank the existence or non-existence of such practices in their respective organization based on a 5 point Likert scale. The financial management practices have been determined using the means response for each statement and the grand mean for each component of financial management practices. The standard deviations of the variables have also been included to show the deviation of the responses from the reported mean. The study also used growth in total assets and growth in sales as a measure of SMEs performance. The average growth in total assets for the sampled SMEs is $12 \%$ whiles average growth in sales $8 \%$.

The result shows the gender distribution of respondents sampled from the companies. The results of the analysis revealed that 38 respondents representing 76 per cent were males whilst 12 respondents also representing 24 per cent were females. It is clear that the majority of the respondents for this study was male(s)

\section{Descriptive Analysis}

Table 1: Descriptive Statistics

\begin{tabular}{lllll}
\hline Variable & \multicolumn{1}{c}{ Mean } & Std. Deviation & \multicolumn{1}{c}{ Min } & \multicolumn{1}{c}{ Max } \\
\hline Age & 12 & 0.9563 & 5 & 24 \\
Total Turnover & $\$ 800,000$ & 0.6574 & $\$ 500,000$ & $\$ 12,000,000$ \\
Total Assets & $\$ 2,000,000$ & 0.5825 & $\$ 200,000$ & $\$ 10,000,000$ \\
Growth in Assets & 0.1245 & 0.4562 & 0.03456 & 0.56734 \\
Growth in Sales & 0.08467 & 0.54276 & 0.5467 & 0.25467 \\
\hline
\end{tabular}

Source: Field Data, 2018

The study also examined some descriptive statistics on the SMEs sampled for the study. The average age of SMEs sampled for the study was 12 years with the least age being 5 years and the maximum age being 24 years. The result is slightly different from the results of Abor (2008) who reported an average age of SME of 9 years. In terms of annual turnover generated by the SMEs sampled for the study, it ranges from GH $\$ 500,000$ to $\mathrm{GH} \$ 12,000,000$ with an average of $\mathrm{GH} \$ 800,000$. As indicated in the methodology, the study sampled only SMEs that have well-established structures and systems operating like big business but not listed on the Stock Exchange and as such meet the definition of SMEs as per IFRS for SMEs. Also, the average total assets of the 
SMEs sampled ranges from $\mathrm{GH} \$ 200,000$ to $\mathrm{GH} \$ 10,000,000$ with average total assets of $\mathrm{GH} \$ 2,000,000$. The growth rates are lower compared to that reported by Abor (2008) where the average SME growth rate was $50 \%$.

\section{Accounting Information Systems and Financial Reporting}

Table 2: Accounting Information System and Financial Reporting Practices

\begin{tabular}{llll}
\hline Elements of AIS \& FR & N & Mean & St. dev \\
\hline $\begin{array}{l}\text { The financial statements of the company are prepared in line with the } \\
\text { financial accounting standards }\end{array}$ & 100 & 4.56 & 0.507 \\
The financial statements are prepared in accordance with GAAP & 100 & 4.50 & 0.586 \\
The financial statements are published regularly & 100 & 3.85 & 0.456 \\
Financial statement is prepared in line with IFRS for SMEs & 100 & 3.15 & 0.764 \\
The company uses accounting information for decision making & 100 & 4.20 & 0.354 \\
Periodic reports are generated by the AIS for decision making & 100 & 4.65 & 0.267 \\
Grand Mean & & 4.18 & \\
\hline
\end{tabular}

The mean responses on accounting information system and financial reporting practices as a major component of financial management practices show that generating periodic reports from the accounting information system for decision making had the highest score of 4.65. This was followed by the preparation of the financial statement in line with financial accounting standards with a mean score of 4.56 and in compliance with GAAP with a mean score of 4.50. The responses with the least mean score were the preparation of a financial statement in compliance with IFRS for SMEs. The results suggest that the majority of the SMEs do not prepare a financial statement in compliance with IFRS for SMEs, even though Ghana adopted it far back in 2009 and its implementation was supposed to have started by 2012. A good accounting information system provides the relevant financial data for financial management and decision making. The results also show how important SMEs view accounting information and financial reporting and analysis to business activities and decision making.

\section{Capital Structure Management of SMEs}

Table 3: Capital Structure Management Practices

\begin{tabular}{llll}
\hline Elements of capital structure management & N & Mean & St. dev \\
\hline The company is conscious about its capital structure & 100 & 4.15 & 0.443 \\
The capital structure of the company is appropriate & 100 & 3.85 & 0.564 \\
The company has fully utilized the debt facility according to its capabilities & 100 & 3.25 & 0.352 \\
The company relies on equity capital only & 100 & 3.0 & 0.674 \\
The company has foreign ownership & 100 & 3.20 & 0.543 \\
The company does not have any challenge raising equity capital compared to debt & 100 & 3.50 & 0.542 \\
The company is able to raise debt capital easily compared to equity & 100 & 4.20 & 0.253 \\
Grand Mean & & 3.14 & \\
\hline
\end{tabular}

The responses from the management of the capital structure of SMEs shows that most SMEs agree that it is easy to raise debt capital as an SME in Ghana and that equity $h$ had a mean score of 4.15. This was followed by the fact that most SMEs are conscious about their capital structure which had a mean score of 4.15. The statement with the least mean score was whether the SMEs rely on only equity as their source of finance. The results suggest that most SMEs use debt and equity capital and that it is easier to raise debt capital than equity capital. The grand mean score for capital structure management is 3.14, lower than accounting practices. This suggests that SMEs take accounting practices more serious than the management of their capital structure. 


\section{Working Capital Management Practices}

Table 4: Working Capital Management Practices

\begin{tabular}{llll}
\hline Elements of working capital management & N & Mean & St. dev \\
\hline The company has a working capital management system & 100 & 3.85 & 0.567 \\
Maintains inventory records which are updated regularly & 100 & 4.82 & 0.235 \\
Optimal cash balances are maintained by the company at all times & 100 & 4.50 & 0.152 \\
Maintains proper records for all payables & 100 & 4.00 & 0.352 \\
Ensures there is sufficient cash flow to meet daily needs & 100 & 4.85 & 0.215 \\
Prepares cash flow forecasts to identify future surpluses and deficits & 100 & 4.40 & 0.327 \\
Grand Mean & & 4.40 & \\
\hline
\end{tabular}

The results from the working capital management practices of SMEs show that ensuring that there is sufficient liquidity to meet daily needs had the highest mean score of 4.85 . This was closely followed by the maintenance of regular inventory records which had a mean score of 4.82. The statement with the least mean score was the company having a working capital management system, and this had a mean score of 3.85. Overall, the mean score for the sampled SMEs' working capital management practices appears higher compared to other variables in the other financial management practices. The grand mean score of 4.40 shows that SMEs take working capital management issues very seriously.

\section{Capital Budgeting and Fixed Assets Management}

Table 5: Capital Budgeting and Fixed Assets Management Practices

\begin{tabular}{llll}
\hline Elements of capital budgeting and fixed assets management & N & Mean & St. dev \\
\hline Use of professional advice in capital investments & 100 & 3.85 & 0.32 \\
Use of capital budgeting technique like payback & 100 & 3.75 & 0.35 \\
Use of capital budgeting techniques like discounted cash flow & 100 & 3.20 & 0.65 \\
Applying capital budgeting techniques in decision-making & 100 & 3.90 & 0.45 \\
The company maintains a non-current assets register & 100 & 4.20 & 0.25 \\
Grand Mean & & 3.00 & \\
\hline
\end{tabular}

The next financial management practice that was examined was the use of a capital budgeting techniques in taking investment decision in the various SMEs and how fixed assets are managed as part of the company's financial management practices. The results in the table above show that keeping fixed assets register had the highest mean score of 4.20. The use of capital budgeting tools for decision making had the second highest mean score of 3.90 under the capital budgeting and fixed assets management practices. This was followed by the firm's use of professionals in capital budgeting decisions with a mean score of 3.85. The use of capital budgeting tools such as payback period had a means score of 3.75 and the use of discounted cash flow techniques had the least mean score of 3.20. The results imply that even though SMEs use capital budgeting techniques in their financial management and investment decision making, the majority use the payback method compared to the discounted cash flow techniques. The results of the descriptive statistics of the financial management practices of SMEs in Ghana show that SMEs' working capital management practice is more serious compared to the other financial management practices.

Working capital management practices reported the highest mean score of 4.40 . This was followed by accounting information and financial reporting practices which showed a grand mean of 4.18. Capital structure management was next with a mean score of 3.14 and SMEs' use of capital budgeting techniques and management of fixed assets achieved the least mean score of 3.0. The results show that on average SMEs in Ghana have some levels of financial management practices in place in their respective organizations. The results are similar to the results of previous studies in other jurisdictions. For instance, Turyahebwa (2013) study on financial management practices of Ugandan SMEs revealed that working capital management practices had the highest mean score of 2.35 while financial reporting and analysis had the least mean score 
of 2.10. Muneer et al. (2017) also reported similar results based on a sample of SMEs in South Africa. Selvanayaki (2016) reported similar findings with a sample of Rice Milling firms in Tamil Nadu.

The Impact of Financial Management Practices on SMEs Profitability: To achieve the second objective of the study which sought to examine the influence of financial management practices on the profitability of SMEs, the Pearson correlation analysis was adopted to achieve the objective of the study. Profitability of SMEs was measured by the average of profit margin, return on assets and return on equity for the sampled SMEs. The study examined how the components of financial management practices, such as an accounting information system and financial reporting practices, working capital management practices, management of capital structure and the use of capital budgeting tools and management of fixed assets all affect the profitability of SMEs. The result of the Pearson Correlation analysis is presented below:

Table 6: Pearson Correlation Analysis for Profitability and Financial Management Practices

\begin{tabular}{llllll}
\hline & Profit & WCM & CSM & AIS\&FR & CBM \\
\hline Profit & 1.00 & & & & \\
WCM & $0.69^{* * *}$ & 1.00 & & & \\
CSM & $0.53^{* *}$ & 0.41 & 1.00 & & \\
AIF\&FR & $0.65^{* * *}$ & 0.35 & 0.19 & 1.00 & \\
CBM & $0.51^{* *}$ & 0.30 & 0.25 & 0.28 & 1.00 \\
\hline
\end{tabular}

*** Significant at $1 \%,{ }^{* *}$ Significant at $5 \%,{ }^{*}$ significant at $10 \%$

The result of the correlation analysis from the Pearson correlation analysis in table 4.4 above shows that there is a positive correlation between working capital management practices (WCM) and profitability of SMEs. The result is also statistically significant at a $1 \%$ significance level. The results improvement in SMEs working capital management practices will improve their overall profitability. The result is consistent with previous studies in the literature and consistent with the expectations of the study. The second variable, capital structure management (CSM) also showed a positive correlation with the profitability of SMEs. The result is also statistically significant at a $5 \%$ significance level. The result shows that improvement in the capital structure management of SMEs improves their financial performance. The result is consistent and confirms the assertion that the capital structure of a firm affects their profitability and as such should be taken seriously by SME owners if they want to maximize their profitability. The third variable, accounting information system and financial reporting practices (AIS \& FR) showed a positive correlation with the profitability of SMEs.

The result is also statistically significant at a 1\% significance level. The results show improvement in SMEs' accounting information systems and financial reporting practices improvements in the profitability of SMEs in Ghana. The result is consistent with previous studies and in line with the expectations of the study. Finally, the results of the Pearson correlation analysis showed a positive correlation between the use of capital budgeting techniques and working capital management and profitability of SMEs in Ghana. The result is also statistically significant at a 5\% significance level. This result implies that SMEs make use of capital budgeting techniques in their investment decisions and management of the firm's fixed assets.

The Impact of Financial Management Practices and Growth of SMEs: The second aspect of the final objective of the study examined the effect of financial management practices on the growth of SMEs in Ghana. The growth of SMEs was measured by the percentage growth in total assets and growth in total sales. The results of the Pearson correlation analysis showing the relationship between financial management practices and the growth of SMEs in Ghana is presented below: 
Table 7: Correlation Analysis between Financial Management Practices and Growth in Total Assets

\begin{tabular}{llllll}
\hline & Growth in Assets & WCM & CSM & AIS\&FR & CBM \\
\hline Growth & 1.00 & & & & \\
WCM & $0.75^{* * *}$ & 1.00 & & & \\
CSM & $0.62^{* *}$ & 0.41 & 1.00 & & \\
AIF\&FR & $0.55^{* *}$ & 0.35 & 0.19 & 1.00 & \\
CBM & $0.70^{* * *}$ & 0.30 & 0.25 & 0.28 & 1.00 \\
\hline
\end{tabular}

${ }^{* * *}$ Significant at $1 \%,{ }^{* *}$ Significant at $5 \%,{ }^{*}$ significant at $10 \%$

Table 8: Correlation Analysis between Financial Management Practices and Growth in Turnover

\begin{tabular}{llllll}
\hline & Growth in Turnover & WCM & CSM & AIS\&FR & CBM \\
\hline Growth & 1 & & & & \\
WCM & $0.68^{* *}$ & 1.00 & & & \\
CSM & $0.4235^{*}$ & 0.41 & 1.00 & & \\
AIF\&FR & $0.756^{* * *}$ & 0.35 & 0.19 & 1.00 & \\
CBM & $0.57^{* *}$ & 0.30 & 0.25 & 0.28 & 1.00 \\
\hline
\end{tabular}

*** Significant at $1 \%,{ }^{* *}$ Significant at $5 \%,{ }^{*}$ significant at $10 \%$

The result from table 4.5 and table 4.6 shows that SMEs' working capital management practices are positively correlated with the growth of SMEs in Ghana. The relationship is statistically significant at a $1 \%$ significance level in the case of total assets growth and 5\% in the case of total turnover growth. The result shows that good working capital management practices of SMEs help them to grow. The results of the Pearson correlation analysis showed a positive correlation between working capital management practices and profitability and growth of SMEs in Ghana. The results confirm the assertion that good working capital management practices improve SMEs' performance in terms of profitability and growth. The result is consistent with the findings of previous studies in Ghana and in other jurisdictions. For instance, the result is consistent with the findings of Selvanayaki (2016), Muneer (2017), Karadag (2015), Turyahebwa (2013) etc.

All these studies reported a positive association between working capital management practices and SMEs performance. The second variable capital structure management (CSM) and this is also positively correlated with the growth of SMEs in Ghana. The result shows that good management of a firm's capital structure helps it to grow. The correlation outcomes exhibited a positive association between capital structure management and performance of SMEs in terms of growth and profitability. The results show that proper management of SMEs financing structure improves their financial performance and helps them to grow. The result is consistent with the findings of previous studies such as Kilonzo and Ouma (2015), Mazzarol (2015) and several other studies. The third variable, accounting information systems and financial reporting practices show a positive correlation with the growth of SMEs. The results show that SMEs with good accounting information systems and financial reporting practices used in decision making improve the growth of SMEs.

The result is statistically significant at a $1 \%$ significance level for both growth in total assets and growth in total turnover. The correlation analysis showed a positive association between accounting information systems and financial reporting practices on the growth and profitability of SMEs. The results confirm the expectations of the study and are in line with the findings of previous studies. Several studies have reported a positive association between bookkeeping and financial reporting and analysis and performance of SMEs as these all provide the required information for management decision making. Firms can properly manage their finances if they have good accounting and financing reporting practices that will generate relevant financial information to support decision making. The results are consistent with the findings of several studies (Musah, 2017; Agbemava et al. 2016; Dawuda \& Azeko, 2015; Owusu et al. 2015; Mutua 2015; Boame 2014; Amoako 2013; Maseko \& Manyani, 2011). 
Finally, the correlation result shows that there is a positive correlation between an SME's use of capital budgeting practices and management of its fixed assets increase their growth. The results are statistically significant at a 1\% significance level for growth in total assets and 5\% significance level for growth in turnover and show that SMEs that use capital budgeting techniques in their investment decisions and proper management of their fixed assets have improvement in their growth. The descriptive statistics, however, showed that even though SMEs believe that the use of capital budgeting techniques improves their performance, it is the least preferred financial management practice among the selected SMEs. Overall, the results of the study revealed that financial management practices improve the financial performance and growth of SMEs in Ghana. The results reveal that when the major component of financial management practices is adopted and practiced in an organization, the organization will experience improvement in its financial performance and growth.

\section{Conclusion}

The results of the study show that when a specific component of financial management practices are properly adopted and implemented, SMEs' performance will improve in terms of profitability and growth. The results revealed that firms that want to improve their financial performance must ensure good working capital management practices, adopt and implement good financing reporting and bookkeeping practices relevant for decision making, manage their capital structure well and adopt capital budgeting techniques and fixed assets management. The descriptive statistics revealed weaknesses in some component of these financial management practices which have to be improved to ensure growth and profitability of these SMEs. It is recommended that the use of capital budgeting techniques be improved, as this area of financial management, even though it impacts positively on the performance of SMEs had the least score. Most importantly, the managers of SMEs should use discounted cash flow techniques to evaluate investment and projects before committing the resources of the company. SMEs are encouraged to adopt IFRS for SMEs to enhance their financial reporting practices. This will also improve their decision making and access to capital which will allow these SMEs to expand.

\section{References}

Abanis, T., Sunday, A., Burani, A. \& Eliabu, B. (2013). Financial management practices in small and medium enterprises in selected districts in Western Uganda. Research Journal of Finance and Accounting, 4(2), 29-42.

Abor, J. (2005). The effect of capital structure on profitability: an empirical analysis of listed firm in Ghana. The Journal of Risk Finance, 6(5), 438-445.

Abor, J. (2008). Determinants of the capital structure of Ghanaian firms. The African Economic Research Consortium.

Abor, J. \& Quartey, P. (2010). Issues in SME development in Ghana and South Africa. International Research Journal of Finance and Economics, 39(6), 215-228.

Abor, J. (2007). Industry Classification and Capital Structure of Ghanaian SME. Studies in Economics and Finance, 24(3), 207-219.

Ademola, G. O., James, S. O. \& Olore, I. (2012). The roles of record keeping in the survival and growth of smallscale enterprises in Ijumu Local Government Area of Kogi State. Global Journal of Management and Business Research, 12(13), 55-66.

Agbemava, E., Ahiase, G., Sedzro, E., Adade, T. C., Bediako, A. K., Nyarko, I. K. \& Kudo, M. B. (2016). Assessing the effects of sound financial statement preparation on the growth of small and medium-scale enterprises. The International Journal of Business \& Management, 4(3), 104-125.

Ahiawodzi, A. K. \& Adade, T. C. (2012). Access to credit and growth of small and medium scale enterprises in the municipality of Ghana. British Journal of Economics, Finance and Management Sciences, 6(2), 3451.

Ahmad, S. Z. \& Muhammad Arif, A. M. (2015). Strengthening access to finance for women-owned SMEs in developing countries. Equality, Diversity and Inclusion: An International Journal, 34(7), 634-639.

Amoako, G. K. (2013). Accounting practices of SMEs: A case study of Kumasi Metropolis in Ghana. International Journal of Business and Management, 8(24), 73-83. 
Arinaitwe, S. K. (2006). Factors constraining the growth and survival of small-scale businesses. A developing countries analysis. Journal of American Academy of Business, Cambridge, 8(2), 167-178.

Boame, I., Solace, K. \& Issaka, S. (2014). Adoption of accounting practices and its effects on SMEs: the financial perspective of sachet water producers in the Northern Region of Ghana. Research Journal of Finance and Accounting, 5(17), 166-179.

Bowen, M., Morara, M. \& Mureithi, M. (2009). Management of business challenges among small and micro enterprises in Nairobi-Kenya. KCA journal of business management, 2(1).

Brigham, E. F. \& Houston, J. F. (2012). Fundamentals of financial management. Cengage Learning.

Brigham, Eugene F. 1995. Financial management: Theory and practice. Hinsdale, Ill.: Dryden Press.

Chandra, P. (2011). Financial management. Tata McGraw-Hill Education.

Chen, J. J., Zheng, B. \& Tan, L. (2013). Agent-based model with asymmetric trading and herding for complex financial systems. PloS one, 8(11), 79531.

Dawuda, A. \& Azeko, I. (2015). An assessment of financial records keeping behaviour of small-scale businesses in Ghana: A case study of Bolgatanga Municipality. International Journal of Finance and Accounting, 4(3), 187-194.

Forkuoh, S. K. \& Li, Y. (2015). Electricity power insecurity and SMEs growth: a case study of the cold store operators in the as a market area of the Kumasi metro in Ghana. Open Journal of Business and Management, 3(03), 312.

Gitman, L. (2011). Principles of Managerial Finance.10th Ed., Addison, Wesley Publishing, 2003, ISBN 020178479-3.

Germain, P. J. (2010, April 9). Top 10 Small Business Bookkeeping Tips.

Isa, C. R., Saleh, Z. \& Sapiei, N. S. (2007, August). Financial and management accounting practices among small and medium enterprises in Malaysia. In International Management Accounting Conference IV (pp. 15-17).

Jindrichovska, I. (2013). Financial management in SMEs. European Research Studies Journal, 16(4), 79-96.

Karadag, H. (2015). Financial management challenges in small and medium-sized enterprises: A strategic management approach. Emerging Markets Journal, 5(1), 25-40.

Kennedy, J., Tennent, B. \& Gibson, B. (2006). Financial management practices in small businesses: regional and metropolitan. Small Enterprise Research, 14(1), 55-63.

Kilonzo J. M. \& Ouma. (2015). Financial management practices on the growth of Small and Medium Enterprises: A case of manufacturing enterprises in Nairobi County, Kenya. IOSR Journal of Business and Management, 17(8), 65-77.

Kitonga, K. G. (2013). The relationship between financial management practices and financial performance in the shipping industry in Kenya. Unpublished MBA project University of Nairobi, Kenya.

Lavia López, O. \& Hiebl, M. R. (2014). Management accounting in small and medium-sized enterprises: current knowledge and avenues for further research.Journal of Management Accounting Research, 27(1), 81-119.

Madurapperuma, M. W., Thilakerathne, P. M. C. \& Manawadu, I. N. (2016). Accounting recordkeeping practices in small and medium-sized enterprises in Sri Lanka. Journal of Finance and Accounting, 4 (4), 188193.

Matsoso, M. L. \& Benedict, O. H. (2014). Non-Financial Performance Measures in Small Medium Enterprises' Supply Chain Management. Journal of Economics, 5(3), 247-257.

Maseko, N. \& Manyani, O. (2011). Accounting practices of SMEs in Zimbabwe: An investigative study of record keeping for performance measurement (A case study of Bindura). Journal of accounting and taxation, 3(8), 158-161.

Mazzarol, T., Reboud, S. \& Clark, D. (2015, July). The financial management practices of small to medium enterprises. In Small Enterprise Association of Australia and New Zealand 28th Annual SEAANZ Conference Proceedings, 1-3.

Mensah, S. (2004, March). A review of SME financing schemes in Ghana. In A Presentation at the UNIDO Regional Workshop of Financing SMEs (pp. 15-16). Ghana: Accra.

Muchira, B. W. (2012). Record Keeping and Growth of Micro and Small Enterprises: A Case Study of Thika Municipality in Kenya. Retrieved on, 15, 11-16.

Muneer, S., Ahmad, R. A. \& Ali, A (2017). Impact of financial management practices on SMEs profitability with moderating role of agency cost, Information Management and Business Review, 9(1), 23-30. 
Musah, A. \& Ibrahim, M. (2014). Record keeping and the bottom line: Exploring the relationship between record keeping and business performance among small and medium enterprises (SMEs) in the Tamale Metropolis of Ghana. Research Journal of Finance and Accounting, 5(2), 107-117.

Musah, A. (2017). Benefits and Challenges of Bookkeeping and Accounting Practices of SMEs and Its Effect on Growth and Performance in Ghana. JABM Journal of Accounting-Business \& Management, 24(2), 16-36.

Mutua, J. M. (2015). Effect of bookkeeping on the growth of small and medium enterprises in Chuka town. European Journal of Business and Social Sciences, 4(7), 102-112.

OECD. (2010). SMEs, Entrepreneurship and Innovation, Paris, Organisation for Economic Co-operation and Development.

Owusu, E. E., Assabil, E. N. \& Asare-Kyire, S. (2015). Assessing the impacts of proper book-keeping on the performance of Small and Medium Scale Enterprises (SMEs) in Kwaebibirem district of Ghana. The International Journal of Science and Technoledge, 3(7), 84-96.

Pandey, 1. (2004). Financial Management. New Delhi - 110014: Vikas Publishing house Pvt. Ltd

Romney, D. (2009). Accounting Information Systems, Upper Saddle River. New Jersey: Pearson Prentice Hall.

Selase Asamoah, E. (2014). Customer-based brand equity (CBBE) and the competitive performance of SMEs in Ghana. Journal of Small Business and Enterprise Development, 21(1), 117-131.

Selvanayaki, S., Sivakumar, S. D., Rohini, A. \& Mani, K. (2016). Financial management practices and profitability of modern rice milling firms in Kangayam Cluster, Tamil Nadu. Agricultural Economics Research Review, 29(2), 297-306.

Tauringana, V. \& Adjapong Afrifa, G. (2013). The relative importance of working capital management and its components to SMEs' profitability. Journal of Small Business and Enterprise Development, 20(3), 453469.

Turyahebwa, A., Sunday, A. \& Ssekajugo, D. (2013). Financial management practices and business performance of small and medium enterprises in western Uganda. African Journal of Business Management, 7(38), 3875.

Uwonda, G., Okello, N. \& Okello, N. G. (2013). Cash flow management utilization by small medium enterprises (SMEs) in northern Uganda. Merit Research Journal of Accounting, Auditing, Economics and Finance, 1(5), 067-080.

Zietlow, J. T., Hankin, J. A. \& Seidner, A. G. Financial Management for non-profit organizations, 2007. Wiley \& Sons. 